\title{
Assessment of damage during the formation and passage of mudflows in the Tashkent region
}

\author{
Farrukh Shaazizov ${ }^{*}$
}

Tashkent institute of irrigation and agricultural mechanization engineers, Tashkent, Uzbekistan

\begin{abstract}
Mountainous and largely foothill areas of the Republic of Uzbekistan are mudflow hazardous. In the Tashkent region, there are two mudflow river basins (dangerous concerning the manifestation of mudflows): the Chirchik river basin and the Akhangaran river basin. Based on the results of long-term observations of the Uzhydromet service, a digital map of the mudflow hazard in the Tashkent region for a century was compiled. The method for determining the damage from the action of mudflows on a specific object consists of determining the equivalent mudflow pressure according to its initial parameters. According to the methodology for assessing damage in the event of a natural emergency, the main parameters of the damaging factors were determined during the passage of a mudflow in the event of intense rainfall. The calculations were performed for two scenarios: 1) with dangerous rainfall with an intensity of $30 \mathrm{~mm}$ per day; 2) in case of especially dangerous rainfall with an intensity of $60 \mathrm{~mm}$ per day. Based on the calculations performed, the amount of damage to the national economy of the Tashkent region was determined during the passage of a mudflow caused by intense rainfall.
\end{abstract}

\section{Introduction}

In the Tashkent region, there are two mudflow river basins (dangerous concerning the manifestation of mudflows): the Chirchik river basin and the Akhangaran river basin.

Based on the results of long-term observations of the Uzhydromet service, a digital map of the mudflow hazard in the Tashkent region for a century was compiled (Fig. 1).

Based on a digital map made on the Arc View 3.2 and ArcGIS 10 platforms, the most dangerous areas of mudflow manifestations were identified, and settlements located in the area of high mudflow activity were identified [1-15].

Below in Table 1, the names of settlements that fall into the high-risk zone are given.

Table 1. Settlements falling into the high-risk zone

\begin{tabular}{|c|c|}
\hline High-risk types & Place names \\
\hline Mudflow hazard & $\begin{array}{c}\text { Kumyshkan, Hisarak, Zarkent, Sukok, Nazdak (Nevich), Jartish, Yangiabad, } \\
\text { Sayazar, Chinar, Chatau, Koksaray, Ertash, Beshkul, Nishbash, Pskem, } \\
\text { Jaujurek, Takayangak, Tepar, Kushbulak, Mulala, Aktash. }\end{array}$ \\
\hline
\end{tabular}

\footnotetext{
* Corresponding author: shosfarruh@mail.ru
} 


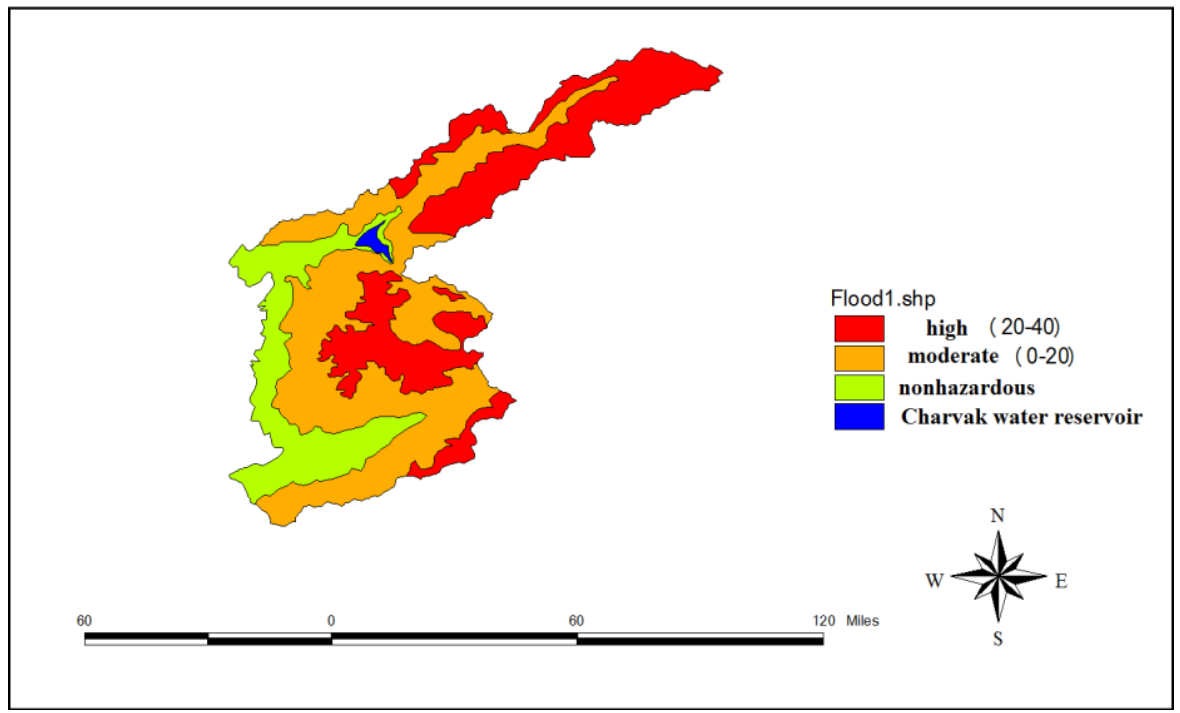

Fig. 1. Map of mudflow hazard in Tashkent region for a century.

The employees of the Ministry of Emergency Situations of the Republic of Uzbekistan provided information on the number of population in the above-mentioned settlements, the number of farms, the number of public facilities, the number of multi-storey houses of residence of the population, and information on the building materials used for buildings.

\section{Methods}

In the presence of certain initial data on the mudflow basin, it seems possible to predict by calculation the processes of movement and transformation of mudflows based on mathematical models describing these processes.

The maximum flow rate $Q_{c}$, the volume $W$ of the outflow, the velocity $V_{c}$ of the mudflow and the distance of its advance $L_{c}$ can be approximately estimated analytically.

The maximum flow rates of mudflow-forming breakthrough $Q^{n}$ and rainfall $Q^{d}$ floods and their volumes $W^{n(d)}$ are determined depending on specific conditions [16-20].

Due to the absence in the study area of the formation of mudflows due to the breakthrough of the ice (ice-ground) bridge formed by natural moraine lakes, further in the calculations, only the case of mudflow formation due to the intense fallout of liquid precipitation (rains) will be considered.

The value of $Q^{d}, \mathrm{~m}^{3} / \mathrm{s}$ of a rain flood, at a precipitation layer height of a given provision, is calculated by the formula:

$$
Q^{d}=K_{c} H_{1} \lambda F
$$

Where: $\boldsymbol{K}_{\boldsymbol{c}}$ is rainfall runoff coefficient, determined from the table. $2 ; \boldsymbol{H}_{\boldsymbol{l}}$ is maximum daily precipitation layer of $1 \%$ availability, determined according to the data of the nearest meteorological station; $\lambda$ is transition coefficient from layers of rainfall runoff of $1 \%$ availability to layers of runoff with a different probability (Table 3.); $\boldsymbol{F}$ is catchment area, $\mathrm{km}^{2}$.

For streams with a short observation series, it is possible to recommend the dependence of the distribution parameter $\lambda$ on the average height of the river basin $(Z)$ : 


$$
\lambda=0.09 Z^{2}+0.52 Z-0.40
$$

Table 2. - The value of the rainfall runoff coefficient $\boldsymbol{K}_{\boldsymbol{c}}$ and the transition coefficient $\lambda$ for the area under consideration

\begin{tabular}{|c|c|c|c|c|c|}
\hline \multirow{2}{*}{ Area } & \multicolumn{3}{|c|}{ The quantity $\lambda, \%$ with the probability of exceeding equal to } & \multirow{2}{*}{$\mathrm{K}_{\mathrm{c}} \times 10^{-3}, \mathrm{~s}^{-1}$} \\
& 0.1 & 1.0 & 5.0 & 10 & \\
\cline { 2 - 5 } & 1.5 & 1.0 & 0.70 & 0.56 & 2.52 \\
\hline Middle Asia & 1.5 &
\end{tabular}

The foothill zone of the Tashkent region covers the Tien Shan mountain system in the range of heights from 300-400 to $600-1000 \mathrm{~m}$ above sea level. The intra-annual distribution of precipitation here is almost the same as in the desert - the maximum in March-April [1][29]. The mountainous zone extends above $600-1000 \mathrm{~m}$ above sea level. The average annual precipitation exceeds $400 \mathrm{~mm}$, in the upper zones of the mountains, on separate windward slopes, more than $2000 \mathrm{~mm}$ can fall. Precipitation falls here all year round, but the maximum is in April-May. More precipitation falls in the mountains on the windward slopes of the Western Tien Shan; at high altitudes, the annual amount of precipitation exceeds $2000 \mathrm{~mm}$. The number of days with precipitation on the flat territory averages 35 60 per year, and in the foothill and mountainous areas is 70-90. Heavy precipitation is quite rare: precipitation of $15 \mathrm{~mm} / 12 \mathrm{~h}$ and more on the plain is not observed annually, and in the mountains, the number of cases increases to 10-15.

Precipitation is considered dangerous, the amount of which in 12 hours or less exceeds $15 \mathrm{~mm}$ in case of rain and $7 \mathrm{~mm}$ in case of snow. The corresponding criterion for especially hazardous precipitation, which is considered a natural phenomenon, is considered to be fallout for the same period of $30 \mathrm{~mm}$ with rain and $20 \mathrm{~mm}$ with snow [21-28].

Summarizing the results given in, it can be noted that:

1. With the expected increase in precipitation, a slight increase in the frequency of mudflows should be expected;

2. For the same reason, an increase in the maximum discharge of mudflow floods is possible;

3. An increase in air temperatures will lead to a decrease in the proportion of mudflows of snow genesis, which, accordingly, will lead to an increase in the proportion of mudflows of rain origin.

In general, there is no reason to expect mitigation of the mudflow hazardous situation in the future.

We carry out calculations for two scenarios:

a) for the case of dangerous rainfall $30 \mathrm{~mm}$ per day;

b) for the case of especially dangerous rainfall - $60 \mathrm{~mm}$ per day.

Considering the above, the magnitude of the rain flood $Q^{d}, \mathrm{~m}^{3} / \mathrm{s}$ along the Pskem and Koksu rivers in the Chirchik river basin and the Akhangaran river basin obtained from formula (1) were:

along the Pskem river - $Q^{d}, \mathrm{~m}^{3} / \mathrm{s}$

a) in case of dangerous rainfall $Q^{d}=288.036 \mathrm{~m}^{3} / \mathrm{s}$

b) in case of especially dangerous rainfall $Q^{d}=576.072 \mathrm{~m}^{3} / \mathrm{s}$

on the river Koksu - $Q^{d}, \mathrm{~m}^{3} / \mathrm{s} \mathrm{F}=174 \mathrm{~km}^{2}$

a) in case of dangerous rainfall $Q^{d}=19.73 \mathrm{~m} 3 / \mathrm{s}$

b) in case of especially dangerous rainfall $Q^{d}=39.46 \mathrm{~m}^{3} / \mathrm{s}$

on the river Akhangaran - $Q^{d}, \mathrm{~m}^{3} / \mathrm{s}$

a) in case of dangerous rainfall $Q^{d}=125.874 \mathrm{~m}^{3} / \mathrm{s}$

b) in case of especially dangerous rainfall $Q^{d}=251.748 \mathrm{~m}^{3} / \mathrm{s}$ 
The volume of water flood $W^{d}, \mathrm{~m}^{3}$, flowing out in case of precipitation with a layer of a given provision, is determined by the formula:

$$
W^{d}=9,5 \times 10^{2} H_{1} \lambda F
$$

on the river Pskem $-W^{d}, \mathrm{~m}^{3}$

a) in the event of dangerous rainfall $\mathrm{W}^{d}=108585000 \mathrm{~m}^{3}$

b) in case of especially dangerous rainfall $\mathrm{W}^{d}=217170000 \mathrm{~m}^{3}$

on the river Koksu $-\mathrm{W}^{d}, \mathrm{M}^{3}$

a) in the event of dangerous rainfall $\mathrm{W}^{d}=7438500 \mathrm{~m}^{3}$

b) in case of especially dangerous rainfall $\mathrm{W}^{\partial}=14877000 \mathrm{~m}^{3}$ on the river Akhangaran - $\mathrm{W}^{\partial}, \mathrm{m}^{3}$

a) in the event of dangerous rainfall $\mathrm{W}^{d}=47452500 \mathrm{~m}^{3}$

b) in case of especially dangerous rainfall $\mathrm{W}^{d}=94905000 \mathrm{~m}^{3}$

Maximum consumption $Q_{c}, \mathrm{~m}^{3} / \mathrm{s}$, of mudflow is determined by the formula:

$$
Q_{c}=\left(1+0.1 l \operatorname{Sin}^{2} \alpha\right) Q^{d}
$$

Where: 1 is the length of the mudflow, $\mathrm{m} ; \alpha$ is slope of the mudflow center, degrees; $Q^{d}$ is the maximum flow rate of the water flow entering the mudflow center, $\mathrm{m}^{3} / \mathrm{s}$. on the river Pskem $-Q_{c}, \mathrm{~m}^{3} / \mathrm{s}$
a) in the event of dangerous rainfall $Q_{c}=2403027 \mathrm{~m}^{3} / \mathrm{s}$
b) in case of especially dangerous rainfall $Q_{c}=4806054 \mathrm{~m}^{3} / \mathrm{s}$ on the river Koksu $-Q_{c}, \mathrm{~m}^{3} / \mathrm{s}$

a) in the event of dangerous rainfall $Q_{c}=59227.49 \mathrm{~m}^{3} / \mathrm{s}$

b) in case of especially dangerous rainfall $Q_{c}=118455 \mathrm{~m}^{3} / \mathrm{s}$ on the river Akhangaran $-Q_{c}, \mathrm{~m}^{3} / \mathrm{s}$

a) in the event of dangerous rainfall $Q_{c}=587589 \mathrm{~m}^{3} / \mathrm{s}$

b) in case of especially dangerous rainfall $Q_{c}=1175178 \mathrm{~m}^{3} / \mathrm{s}$

Volume $W_{c}, \mathrm{~m}^{3}$, mudflow is calculated by the formula:

$$
W_{c}=\left(1+0,12 l \operatorname{Sin}^{2} \alpha\right) W^{d}
$$

on the river Pskem $-W_{c}, \mathrm{~m}^{3}$

a) in the event of dangerous rainfall $W_{c}=1,08706 \mathrm{E}+12 \mathrm{~m}^{3}$

b) in case of especially dangerous rainfall $W_{c}=2.17412 \mathrm{E}+12 \mathrm{~m}^{3}$ on the river Koksu - $W_{c}, \mathrm{~m}^{3}$

a) in the event of dangerous rainfall $W_{c}=26791898780 \mathrm{~m}^{3}$

b) in case of especially dangerous rainfall $W_{c}=53583797561 \mathrm{~m}^{3}$ on the river Akhangaran - $W_{c}, \mathrm{~m}^{3}$

a) in the event of dangerous rainfall $W_{c}=2.65805 \mathrm{E}+11 \mathrm{~m}^{3}$

b) in case of especially dangerous rainfall $W_{c}=5.31609 \mathrm{E}+11 \mathrm{~m}^{3}$

Advance speed $V_{c}, \mathrm{~m} / \mathrm{s}$, mudflow can be calculated using the formula:

$$
V_{c}=11,4 \sqrt{h} \times \sqrt[3]{v_{0} \operatorname{Sin} \alpha}
$$


where: $v_{0}$ is relative hydraulic size of stone materials involved in the flow; $\alpha$ is mean slope of mudflow channel, degrees; $h$ is average flow depth, m. For a quick assessment, the value $h$ usually taken: for low-power flow $1.0 \ldots 1.5 \mathrm{~m}$; for an average power flow of $2 \ldots 3$ $\mathrm{m}$; for powerful flow $3 \ldots 5 \mathrm{~m}$; $\mathrm{v}_{0} \sim 0.7 \ldots 1.0$;

When determining the speed of the mudflow, we take for two cases: for slopes $10^{\circ}$

a) in the event of dangerous rainfall $(\mathrm{h}=2) V_{c}=10.0 \mathrm{~m} / \mathrm{s}$

b) in case of especially dangerous rainfall $(\mathrm{h}=3) V_{c}=14.0 \mathrm{~m} / \mathrm{s}$ for slopes $20^{\circ}$

a) in the event of dangerous rainfall $(\mathrm{h}=2) V_{c}=12.8 \mathrm{~m} / \mathrm{s}$

b) in case of especially dangerous rainfall $(\mathrm{h}=3) V_{c}=16.0 \mathrm{~m} / \mathrm{s}$

The movement distance $\boldsymbol{L}_{\boldsymbol{c}}$ of mudflows is determined in two stages.

At the first stage, the distance of $\boldsymbol{L}_{1}$ advance is calculated, m, mudflow in the river valley

$$
L_{1}=\frac{12.1 W_{c} i}{d B}
$$

where $W_{c}$ is mudflow volume, $\mathrm{m}^{3} ; i$ is mean slope of the valley; $d$ is average diameter of anchoring debris, taken: for mudflow incisions $0.5 \ldots 0.8 \mathrm{~m}$, for potholes $0.3 \ldots 0.4 \mathrm{~m}$ and for foci of dispersed mudflow formation $0.1 \ldots 0.2 \mathrm{~m} ; B$ is average distance between mudflow coastal ramparts.

At the second stage, the advance distance is calculated $\mathrm{L}_{2}, \mathrm{~m}$, debris flow. The calculation is made under the condition $L_{l}>L_{d}$ According to the formula:

$$
L_{2}=\sqrt{36,6 \frac{\left(W_{c}-d B L_{d}\right) i_{k}}{d}}
$$

where: $i_{K}$ is average taper slope; $L_{d}$ is distance from the end of the seedbed to the tops of the fan, $m$.

Mudflow advance range $L_{c}$ defined similarly $L_{l}$, if $L_{l}>L_{d}$. If $L_{l}<L_{d}$, then the value $L_{c}$ is defined as the sum $L_{c}=L_{d}+L_{2}$.

The consequences of mudflows impact on objects are assessed taking into account two indicators: mudflow hazard and mudflow activity using a complex criterion called reduced mudflow activity:

$$
\bar{P}=\sum \frac{W_{T}}{T}
$$

where $\Sigma W_{T}$ is the total volume of mudflows over a certain long period of time $T$.

Due to the lack of data on the total volume of mudflows in the basins of the rivers under consideration, we apply the classification of basins available in the literature according to the height of the sources of mudflows, according to which there are the following zones:

1- Alpine mudflow zones. The headwaters lie above $2500 \mathrm{~m}$, the volume of outflows from $1 \mathrm{~km}^{2}$ is $15-25$ thousand $\mathrm{m}^{3}$ per mudflow.

2- Mid-mountain mudflow zones. The sources lie within $1000-2500 \mathrm{~m}$, the volume of removal from $1 \mathrm{~km} 2$ is $5-15$ thousand $\mathrm{m}^{3}$ per mudflow;

3- Low-mountain mudflow zones. The sources lie below $1000 \mathrm{~m}$, the volume of outflow from $1 \mathrm{~km} 2$ is less than 5 thousand $\mathrm{m}^{3}$ per mudflow.

According to this classification: 
- the valleys of the considered rivers Pskem, Koksu and Akhangaran pass through the middle-mountain mudflow zone. The volume of removals per mudflow is 5-15 thousand $\mathrm{m}^{3}$;

According to fig. 1 the frequency of occurrence of mudflows over hundred years along the Pskem river is 10-20 mudflows on the river Koksu 20-40 mudflows; along the Akhangaran river 5-10 mudflows.

Considering the above, you can calculate the volume of mudflows:

on the Pskem river basin $\quad \Sigma W_{100}=15000 \mathrm{~m}^{3} \times 20$ селей $=300000 \mathrm{~m}^{3}, \bar{P}=3000 \mathrm{~m}^{3}$;

on the Koksu river basin $\quad \Sigma W_{100}=15000 \mathrm{~m}^{3} \times 40$ селей $=600000 \mathrm{~m}^{3}, \bar{P}=6000 \mathrm{~m}^{3}$;

on the Akhangaran river basin $\Sigma W_{100}=15000 \mathrm{~m}^{3} \times 10$ селей $=150000 \mathrm{~m}^{3}, \bar{P}=1500 \mathrm{~m}^{3}$.

According to the above classification in terms of the reduced mudflow activity, all the river basins under consideration belong to the second class - a highly mudflow zone.

The category of mudflow hazard determines the type of mudflows, the passage of which is most typical for a given area. So, for the II category, medium-strong and powerful mudflows are characteristic.

To assess the consequences of the impact of a mudflow on specific types of buildings and structures, the value of the equivalent pressure $\mathrm{P}$ on the walls is used as the main criterion. At speeds of mudflow movement, usually not exceeding $20 \mathrm{~m} / \mathrm{s}$, the impact on the structure is quasi-static. The total pressure $\mathrm{P}$ is determined by the hydrostatic pressure, the velocity head of the flow, and the object's geometry (i.e., the initial impulse of the collision of the mudflow front with the object can be neglected).

When a debris flow acts on the plane of an object perpendicular to the direction of flow, the pressure $\mathrm{P}$ at a point at a depth of $\mathrm{Y}$ is determined by the formula

$$
P=P_{c}+P_{g}
$$

where: $P_{c}=p g Y$ is static pressure, $\rho$ is flux density, $g$ is acceleration of gravity,

$$
\begin{gathered}
\rho=1.9 * 10^{3} \mathrm{~kg} / \mathrm{m}^{3} \\
g=9.81 \mathrm{~m} / \mathrm{s}^{2}
\end{gathered}
$$

static pressure $P_{c}$ we define for conditions:

a) in the event of dangerous rainfall $(\mathrm{h}=2 \mathrm{~m}) Y=2 \mathrm{~m}$

$$
P_{c}=0.037278 M P a\left(0.37278 \kappa G / \mathrm{cm}^{2}\right) .
$$

b) in case of especially dangerous rainfall $(\mathrm{h}=3 \mathrm{M}) Y=3 \mathrm{M}$

$$
P_{c}=0.055917 M P a\left(0.5591 \mathrm{kG} / \mathrm{cm}^{2}\right) .
$$

$P_{g}$ is the mudflow pressure head is determined by the formula:

$$
P_{g}=\frac{C \rho V_{c}^{2}}{2}
$$

where: $C$ is interaction coefficient; $V_{c}$ is seed advance speed, $\mathrm{m} / \mathrm{s}$.

Here we consider the case of the action of the mudflow along the normal to the wall $C=1$. for slopes $10^{\circ}$ 
a) in the event of dangerous rainfall $(\mathrm{h}=2) V_{c}=10.0 \mathrm{~m} / \mathrm{s}$

$$
P_{g}=0.095 \mathrm{MPa}
$$

b) in case of especially dangerous rainfall $(\mathrm{h}=3) V_{c}=14.0 \mathrm{~m} / \mathrm{s}$

$$
P_{g}=0.1862 \mathrm{MPa}
$$

for slopes $20^{\circ}$

a) in the event of dangerous rainfall $(\mathrm{h}=2) V_{c}=12.8 \mathrm{~m} / \mathrm{s}$

$$
P_{g}=0.155648 \mathrm{MPa}
$$

c) in case of especially dangerous rainfall $(\mathrm{h}=3) V_{c}=16.0 \mathrm{~m} / \mathrm{s}$

$$
P_{g}=0.2432 \mathrm{MPa}
$$

The total displacement force acting on the object is determined by the formula:

$$
N=F\left(P_{\text {average }}+P_{g}\right) ; P_{\text {average }}=\frac{\rho g H}{2}
$$

where: $F$ is the area of the projection of the streamlined part of the object onto the plane perpendicular to the direction of the mudflow movement, $H$ is flow depth.

\section{Results and discussion}

According to the performed calculations, the value of the equivalent mudflow pressure according to its initial parameters for two possible scenarios:

- In the event of dangerous rainfall (30mm / day) changes from 0.909112 to 1.394296 $\mathrm{MPa}$

In the event of a particularly dangerous rainfall ( $60 \mathrm{~mm} /$ day), it changes

from 2.569902 to $3.253902 \mathrm{MPa}$

With the passage of a mudflow and pressure, low-rise brick buildings, frameless, covered with reinforced concrete elements, have sat down with such a load.

Considering the above and considering that most of the private farms located in the mountainous area are a one-story brick building, they will all completely collapse.

From the information provided by the employees of the Ministry of Emergency Situations of the Republic of Uzbekistan, there are also multi-storey buildings with steel and reinforced concrete frames in the high-risk zone. 
Table 3. The main results of the calculations carried out to assess the cost of damage when the mudflow passes through the mountainous regions of the Tashkent region

\begin{tabular}{|l|c|c|c|c|c|c|c|}
\hline $\begin{array}{c}\text { Name } \\
\text { city and } \\
\text { district }\end{array}$ & $\begin{array}{c}\text { number } \\
\text { of } \\
\text { destroye } \\
\text { d farms }\end{array}$ & $\begin{array}{c}\text { assessmen } \\
\text { t of the } \\
\text { cost of } \\
\text { damage } \\
\text { (million } \\
\text { sums) }\end{array}$ & $\begin{array}{c}\text { number of } \\
\text { destroyed } \\
\text { public } \\
\text { buildings }\end{array}$ & $\begin{array}{c}\text { assessmen } \\
\text { t of the } \\
\text { cost of } \\
\text { damage } \\
\text { (million } \\
\text { sums) }\end{array}$ & $\begin{array}{c}\text { number } \\
\text { of } \\
\text { destroye } \\
\text { d } \\
\text { building } \\
\text { s }\end{array}$ & $\begin{array}{c}\text { assessmen } \\
\text { t of the } \\
\text { cost of } \\
\text { damage } \\
\text { (million } \\
\text { sums }\end{array}$ & $\begin{array}{c}\text { final } \\
\text { estimate } \\
\text { of the cost } \\
\text { of damage } \\
\text { (million } \\
\text { sums) }\end{array}$ \\
\hline $\begin{array}{l}\text { Parkent } \\
\text { district }\end{array}$ & 6279 & 55462.41 & 18 & 1075.75 & 50 & 3579.32 & 60117.48 \\
\hline Angren & 623 & 5502.96 & 3 & 179.29 & 67 & 3688.70 & 9370.95 \\
\hline $\begin{array}{l}\text { Akhangar } \\
\text { an region }\end{array}$ & 793 & 7004.57 & 6 & 358.58 & & & 7363.15 \\
\hline $\begin{array}{l}\text { Bostanlyk } \\
\text { district }\end{array}$ & 2541 & 22444.65 & 5 & 298.82 & & & 22743.47 \\
\hline $\begin{array}{l}\text { Total for } \\
\text { Tashkent } \\
\text { region }\end{array}$ & & & & & & & \\
\hline
\end{tabular}

\section{Conclusions}

Summing up, the following can be noted:

1. With the formation of the passage of a mudflow, formed by intense rainfall on the territory of the Tashkent region, two dangerous areas are distinguished:

- open to the west valley of the Chirchik river, where the maximum average frequency of heavy precipitation is 2-3 cases (half a day) per year;

- open to the southwest valley of the Akhangaran river with a maximum average frequency of 3-6 cases per year.

2 The foothill zone of the Tashkent region covers the Tien Shan mountain system in the range of heights from $300-400$ to $600-1000 \mathrm{~m}$ above sea level. The intra-annual distribution of precipitation here is almost the same as in the desert - maximum in March-April. The mountainous zone extends above $600-1000 \mathrm{~m}$ above sea level. The average annual precipitation exceeds $400 \mathrm{~mm}$, in the upper zones of the mountains, on separate windward slopes, more than $2000 \mathrm{~mm}$ can fall. Precipitation falls here all year round, but the maximum is in April-May. More precipitation falls in the mountains on the windward slopes of the Western Tien Shan; at high altitudes, the annual amount of precipitation exceeds $2000 \mathrm{~mm}$.

3 Based on a digital map made on the platforms Arc View 3.2 and ArcGIS 10, the most dangerous areas of mudflows were identified, and settlements located in the area of high mudflow activity were identified.

4 According to the methodology for assessing damage in the event of a natural emergency, the main parameters of the damaging factors were determined during the passage of a mudflow flood with intense rainfall. The calculations were carried out for two scenarios: 1) with dangerous rainfall with an intensity of $30 \mathrm{~mm}$ per day; 2) in case of especially dangerous rainfall with an intensity of $60 \mathrm{~mm}$ per day.

5 To assess the economic damage during the passage of the mudflow, the ANNEX to the National Standard for Property Valuation of the Republic of Uzbekistan (NSOI No. 12) "Assessment of the value of the real estate by mass valuation methods" 
6 According to the calculations:

a) during the passage of a mudflow, formed as a result of especially dangerous rainfall with an intensity of $60 \mathrm{~mm}$ per day, the damage will be 99.59505 billion sums.

b) during the passage of a mudflow formed from dangerous rainfall with an intensity of 30 $\mathrm{mm}$ per day, the damage will be: 97.3773 billion sums.

\section{References}

1. F. Shaazizov, A. Badalov, A. Ergashev, and D. Shukurov, "Studies of rational methods of water selection in water intake areas of hydroelectric power plants," in E3S Web of Conferences, 2019, vol. 97, doi: 10.1051/e3sconf/20199705041.

2. F. Shaazizov and D. Shukurov, "Physical modeling of the filtration process through the dam base," in IOP Conference Series: Materials Science and Engineering, 2020, vol. 869, no. 7, doi: 10.1088/1757-899X/869/7/072037.

3. F. Shaazizov, A. Badalov, D. Shukurov, and D. Yulchiev, "Hydraulic elevator for cleaning sediment of a water outlet of a reservoir," in IOP Conference Series: Materials Science and Engineering, 2020, vol. 883, no. 1, doi: 10.1088/1757899X/883/1/012018.

4. D. Bazarov, F. Shaazizov, and S. Erjigitov, "Transfer of Amudarya flowing part to increase the supportability of the Uzbekistan southern regions," in IOP Conference Series: Materials Science and Engineering, 2020, vol. 883, no. 1, doi: 10.1088/1757899X/883/1/012068.

5. F. Shaazizov, B. Uralov, E. Shukurov, and A. Nasrulin, "Development of the computerized decision-making support system for the prevention and revealing of dangerous zones of flooding," in E3S Web of Conferences, 2019, doi: 10.1051/e3sconf/20199705040.

6. A. Anarbaev et al., "Determination the installation efficiency of the evaporative air cooling in the greenhouse by temperature-moisture regime," in IOP Conference Series: Earth and Environmental Science, 2020, vol. 614, no. 1, doi: 10.1088/1755$1315 / 614 / 1 / 012026$.

7. A. Anarbaev et al., "Calculation the dynamic stability zone of the distribution grid with generating sources based on renewable energy," in IOP Conference Series: Earth and Environmental Science, 2020, vol. 614, no. 1, doi: 10.1088/17551315/614/1/012004.

8. A. Anarbaev et al., "Using of evaporative cooling systems in poultry farms," in IOP Conference Series: Earth and Environmental Science, 2020, vol. 614, no. 1, doi: 10.1088/1755-1315/614/1/012015.

9. J. Shen et al., "A new multiple return-period framework of flood regulation serviceapplied in Yangtze River basin," Ecol. Indic., vol. 125, 2021, doi: 10.1016/j.ecolind.2021.107441.

10. I. A. Bouchedjera, L. Louail, and Z. Aliouat, "Addressing and flood-based communications for the software-defined metamaterial paradigm," Nano Commun. Netw., vol. 28, 2021, doi: 10.1016/j.nancom.2020.100336.

11. X. Guan, Y. Zhang, Y. Meng, Y. Liu, and D. Yan, "Study on the theories and methods of ecological flow guarantee rate index under different time scales," Sci. Total Environ., vol. 771, 2021, doi: 10.1016/j.scitotenv.(2021).145378.

12. S. Takayama, M. Fujimoto, and Y. Satofuka, "Amplification of flood discharge caused by the cascading failure of landslide dams," Int. J. Sediment Res., vol. 36, no. 3, pp. 430-438, 2021, doi: 10.1016/j.ijsrc.(2020.10.007)

13. M. Kanti Sen, S. Dutta, A. H. Gandomi, and C. Putcha, "Case Study for Quantifying Flood Resilience of Interdependent Building-Roadway Infrastructure Systems," 
ASCE-ASME J. Risk Uncertain. Eng. Syst. Part A Civ. Eng., vol. 7, no. 2, 2021, doi: 10.1061/AJRUA6.0001117.

14. Y.-E. Chen, C. Li, C.-P. Chang, and M. Zheng, "Identifying the influence of natural disasters on technological innovation," Econ. Anal. Policy, vol. 70, pp. 22-36, 2021, doi: 10.1016/j.eap.(2021.01.016)

15. I. M. Kourtis and V. A. Tsihrintzis, "Adaptation of urban drainage networks to climate change: A review," Sci. Total Environ., vol. 771, 2021, doi: 10.1016/j.scitotenv.(2021).145431.

16. K. Yamamoto, T. Sayama, and Apip, "Impact of climate change on flood inundation in a tropical river basin in Indonesia," Prog. Earth Planet. Sci., vol. 8, no. 1, 2021, doi: 10.1186/s40645-020-00386-4.

17. H. Du, H. Wang, Z. Chi, N. Song, C. Wang, and H. Xu, "Burst of hydroxyl radicals in sediments derived by flooding/drought transformation process in Lake Poyang, China," Sci. Total Environ., vol. 772, 2021, doi: 10.1016/j.scitotenv.(2021).145059.

18. H. Eakin, J. Parajuli, Y. Yogya, B. Hernández, and M. Manheim, "Entry points for addressing justice and politics in urban flood adaptation decision making," Curr. Opin. Environ. Sustain., vol. 51, pp. 1-6, 2021, doi: 10.1016/j.cosust.(2021.01.001)

19. Y. Xing, D. Shao, X. Ma, S. Zhang, and G. Jiang, "Investigation of the importance of different factors of flood inundation modeling applied in urbanized area with variance-based global sensitivity analysis," Sci. Total Environ., vol. 772, 2021, doi: 10.1016/j.scitotenv.(2021).145327.

20. M. Wang, S. Wang, J. Zhao, W. Ju, and Z. Hao, "Global positive gross primary productivity extremes and climate contributions during 1982-2016," Sci. Total Environ., vol. 774, 2021, doi: 10.1016/j.scitotenv.(2021).145703.

21. M. Oukacine, S. Proust, F. Larrarte, and N. Goutal, "Experimental flows through an array of emerged or slightly submerged square cylinders over a rough bed," Sci. Data, vol. 8, no. 1, 2021, doi: 10.1038/s41597-020-00791-w.

22. Y. Hirabayashi, M. Tanoue, O. Sasaki, X. Zhou, and D. Yamazaki, "Global exposure to flooding from the new CMIP6 climate model projections," Sci. Rep., vol. 11, no. 1, 2021, doi: 10.1038/s41598-021-83279-w.

23. S. Wolf, V. Esser, H. Schüttrumpf, and F. Lehmkuhl, "Influence of 200 years of water resource management on a typical central European river. Does industrialization straighten a river?," Environ. Sci. Eur., vol. 33, no. 1, 2021, doi: 10.1186/s12302-02100460-8.

24. Q. Wang and J. Chen, "Spatio-temporal evaluation of the emergency capacity of the cross-regional rain-flood disaster in the Yangtze River Economic Belt in China," Sci. Rep., vol. 11, no. 1, 2021, doi: 10.1038/s41598-021-82347-5.

25. J. Boulange, N. Hanasaki, D. Yamazaki, and Y. Pokhrel, "Role of dams in reducing global flood exposure under climate change," Nat. Commun., vol. 12, no. 1, 2021, doi: 10.1038/s41467-020-20704-0.

26. A. K. Mishra, "Observing a severe flooding over southern part of India in monsoon season of 2019," J. Earth Syst. Sci., vol. 130, no. 1, 2021, doi: 10.1007/s12040-02001509-7.

27. R. R. Chaudhuri and P. Sharma, "An integrated stochastic approach for extreme rainfall analysis in the National Capital Region of India," J. Earth Syst. Sci., vol. 130, no. 1, 2021, doi: 10.1007/s12040-020-01510-0.

28. S. Natarajan and N. Radhakrishnan, "Simulation of rainfall-runoff process for an ungauged catchment using an event-based hydrologic model: A case study of koraiyar basin in Tiruchirappalli city, India," J. Earth Syst. Sci., vol. 130, no. 1, 2021, doi: 10.1007/s12040-020-01532-8. 